\title{
THERESE FUHRER
}

\section{The Question of Genre and Metre in Catullus' Polymetrics}




\title{
The Question of Genre and Metre in Catullus' Polymetrics
}

\author{
Therese Fuhrer
}

\section{The Character of Catullus' Polymetrics}

A characteristic feature of Catullus' polymetric poems is the variety of genres and metres ${ }^{1}$. The genres, however, of the individual poems are not clearly distinguishable but seem to overlap. For the content and motifs of many of the poems we find numerous parallels in the Greek Antholoy; but almost all the epigrams there are written in elegiac metre, whereas Catullus' poems are mainly written in hendecasyllables. For example, the first carmen in Catullus' collection can be compared with the prefatory poem to Meleager's Garland $(A . P .4,1)^{2}$. For the sparrow poems (2 and 3 ) one can find nearly 30 parallels in the Greek Antholo$g y$, all written in elegiac couplets ${ }^{3}$. Carmen 4 , in iambic trimeters, could be called a modified dedicatory epigram ${ }^{4}$. Carmen 6 , where the

1 The term 'genre' is applied here and later on in this paper (a) to the larger categories of iambic, elegiac and melic poetry (on the latter $\mathrm{cf}$. $\mathrm{n}$. 16 below), but also

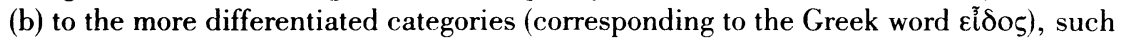
as epikedion, epithalamion, propemptikon, epinikion etc. Cf. M. Puelma Piwonka,

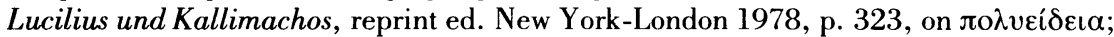
W. Rösler, Poetica 16, 1984, p. 19lf., who would prefer to restrict the term 'genre' (Gattung) to these more differentiated categories; and, most recently, L. Käppel, Paian, Berlin-New York 1992, pp. 3-22.

${ }^{2}$ For parallels to Greek poetry in the Catullan poems mentioned here cf. the commentaries by W. Kroll (reprint ed. Stuttgart 1980); C.J. Fordyce (Oxford 1961); F. Della Corte (Rome 1977); K. Quinn (reprint ed. London-Basingstoke 1985); H.P. Syndikus, Catull: Eine Interpretation I: Die kleinen Gedichte (1-60), Darmstadt 1984. On C. 1 cf. also N. Krevans, The Poet as Editor: Callimachus, Virgil, Horace, Propertius and the Development of the Poetic Book, Diss. Princeton 1984, pp. 311-317.

${ }^{3}$ Cf. esp. A.J. Wheeler, Catullus and the Tradition of Ancient Poetry, BerkeleyLos Angeles 1934, p. 223.

${ }^{4}$ Cf. O. Hezel, Catull und das griechische Epigramm, Stuttgart 1932, pp. 9-14. 
poet exhorts his friend to confess his love, picks up themes occurring in Callimachus' erotic epigrams (Epigr. 30 and 43 Pf.; fr. 714 Pf.; cf. A.P. 5, 181 and 174; also Cat. C. 55) ${ }^{5}$. The invitation to Fabullus $(C$. 13 ) is often compared with Philodemus' invitation to his patron Piso (A.P. 11, 44; cf. 5, 183) ${ }^{6}$. Carmen 26, where Catullus mocks at Furius' debts, also draws on a Greek model (Callim. Epigr. 47 Pf. $)^{7}$. Carmen 27 stands in the tradition of the Hellenistic sympotic epigrams (e.g. Callim. Epigr. $29 \mathrm{Pf}$. $)^{8}$. In $C .46$ we recognize elements of the spring poems in the Greek Anthology ${ }^{9}$. We could continue our list of parallels with poems involving literary, scoptic, abusive, erotic, and obscene subjects, for the Hellenistic epigrams offer an almost unlimited variety of topics and thus models ${ }^{10}$. Even where we would say that Catullus does not use a particular Greek poem as a model or is only to a small degree dependent on a Greek source, he is still obviously continuing and practising Greek types which we find in the Greek Anthology ${ }^{11}$. Yet there are poems in Catullus' polymetrics - especially the translation of

5 Ibid. (n. 4), p. 49 f.

6 Wheeler (n. 3), p. 323f.; Hezel (n. 4), pp. 16-21; R. Reitzenstein, s.v. 'Epigramm', R.E. VI, 1907, col. 98.

7 Wheeler (n. 3), p. 234f.

8 Ibid. p. 235 f.

${ }^{9}$ Hezel (n. 4), pp. 21-26; R. Avallone, Catullo e i suoi modelli II, Napoli 1946 , pp. 242-247.

${ }^{10}$ Cf. esp. Hezel (n. 4), passim; also Wheeler (n. 3), pp. 218-241; Avallone (n. 9), passim; G. Lafaye, Catulle et ses modèles, Paris 1894, passim.

11 Of course, themes from Hellenistic epigrams are also used in Catullus' short poems written in elegiac couplets (cf. e.g. $70 ; 80 ; 85 ; 92 ; 93 ; 95 ; 99 ; 101$, etc.; for literature cf. n. 10, and E. Paratore, in Miscellanea di studi alessandrini in memoria di Augusto Rostagni, Torino 1963, pp. 562-587). But there Catullus gives them the traditional form. Reitzenstein (n. 6), col. 102, thinks that for Catullus the epigram was just a short poem, and the metrical form made no difference to him when he turned motifs from the Greek elegiacs into lyric and iambic metres. But cf. Syndikus (n. 2), pp. 67-70, on the difference between the Catullan polymetrics and elegiac poems; also D.O. Ross, Style and Tradition in Catullus, Cambridge 1969, who sees the elegiac metre bound to an already existing Roman tradition, whose rules Catullus had to follow, namely that of the invective. This is the reason why, according to Ross (esp. p. 153), Catullus when he is imitating, translating, or in anv wav making use of Creek epigrams does so in his polymetrics and not in the elegiacs.

On the influence of the Hellenistic epigrams on some of Horace's lyric pieces ef. R.G.M. Nisbet-M. Hubbard, A Commentary on Horace: Odes Book 1, reprint ed. Oxford $1980^{2}$, p. XIV. 
Sappho's fr. 31 L.-P. (C. 51) and the hymn to Diana (C. 34), but also other poems in different kinds of metres - which clearly go beyond what we could call an epigram ${ }^{12}$ not only in length but also in character (e.g. $8 ; 11 ; 17 ; 76)$. Moreover, not only the great variety of subjects in the first third of the Catullan corpus is striking, but also the miscellany of metres (hendecasyllables and several other Aeolic metres, choliambs and several other iambic metres); and there does not seem to be a consistent connection between form and content. There are invective poems that are written in lyric metres, i.e. in hendecasyllabics ${ }^{13}$ or Sapphic stanzas ( $C .11$ ), instead of iambics; on the other hand, poems 8 (miser Catulle) and 31 (the Sirmio poem), which are choliambic, are not abusive in content ${ }^{14}$. Wilamowitz explains the confusion thus: "Catullus never asked the question 'whether has was allowed' when in the creative mood of the moment this or that Greek poetic form came to his lips"15.

But there seems to be more behind this confusion, more to the character and composition of the Catullan polymetrics. In this paper I address the question: why does Catullus in these poems mix different genres (epigram, iambic, melic ${ }^{16}$ ) and different metres in such an unconventional way? There is more than one possible explanation, as there probably was more than one source of inspiration or influence for Neoteric poetry ${ }^{17}$, and, in fact, different scholars have pointed out different sources. I will now examine those scholars' considerations

12 However, Valerius Aedituus wrote an epigram based on Sappho's fr. 31; cf. Wheeler (n. 3), p. 70.

$136 ; 12 ; 15 ; 16 ; 21 ; 23 ; 24 ; 28 ; 33 ; 40-43 ; 47 ; 53 ; 54 ; 57$.

14 But cf. n. 54 below.

15 U. v. Wilamowitz-Moellendorff, Sappho und Simonides, Berlin $1966^{2}$, p. 293: "Catull fragte eben nicht danach, ob er es dürfte, wenn ihm in der schöpferischen Stimmung des Augenblicks diese oder jene Form der griechischen Poesie auf die Lippen kam".

16 The term 'melic' is used in this paper to denote the poetry which is neither epic nor dramatic nor iambic nor elegiac; the term 'lyric metre', however, is used to denote the metre of the melic poetry. On this terminological problem cf. R. Pfeiffer, History of Classical Scholarship, Oxford 1968, p. 182f.; Rösler (n. 1), pp. 191-194; T. Gelzer, 'Die Alexandriner und die griechischen Lyriker', Acta Ant. Hung. 30, 1988, pp. 137f. and 146.

17 On the question whether or not Catullus' collection represents also the other Neoteric poetry of his time cf. K. Deichgräber, 'Ueberlegungen zu den Gedichten und Gedichtbüchern der Neoteriker', Hermes 99, 1971, pp. 66-68; R.O.A.M. Lyne, 'The 
(which often are not yet elaborated) and the evidence we have and try to explain the apparent chaos of genre and metre in Catullus' polymetric poems. The possible sources will be reviewed in reversed chronological order to give an idea of the spiritual and intellectual background of Catullus' literary world and to detail the poetic tradition to which he was heir ${ }^{18}$.

\section{The Garland of Meleager}

About a generation before Catullus, the Garland of Meleager was arranged, in which epigrams were grouped together with other small poems in varying metres ${ }^{19}$. Although the poems now extant which we know were once in the Garland are almost exclusively in elegiac metre, we can assume that the collection must have contained a considerable number of pieces in various lyric metres as well, for in his prefatory poem $(A . P .4,1)$ Meleager mentions Archilochus and Sappho among the 48 writers, including himself, whose poems were collected in the Garland. Perhaps Catullus was inclined to follow this Greek precedent and thus felt no constraint against mixing poems in iambic metres, hendecasyllables, Sapphic stanzas, and glyconic combinations as well as the

Neoteric Poets', Class. Quart. 28, 1978, pp. 167-187; E. A. Schmidt, Catull, Heidelberg 1985, pp. 71-76.

18 The present paper does not address the question of the arrangement of Catullus' poems. Its arguments, however, are based on the assumption that Catullus did edit either the whole or part of the collection as a poetic book.

Many critics now think that the arrangement as it is preserved by the Verona manuscript does not correspond to the Catullan libellus (for literature cf. E.A. Schmidt, 'Das Problem des Catullbuches', Philologus 123, 1979, pp. 216-231; M. S. Santirocco, 'Horace's Odes and the Ancient Poetry Book', Arethusa 13, 1980, p. 48f.; Krevans [n. 2], pp. 309-317). Cf. esp. W. Clausen, Class. Philol. 71, 1976, pp. 37-43; T.K. Hubbard, 'The Catullan Libellus', Philologus 127, 1983, pp. 218-237; W. Stroh, 'Lesbia und Juventius: Ein erotisches Liederbuch im Corpus Catullianum', in P. Neukam (ed.), Die Antike als Begleiterin, München 1989, pp. 134-157; Clausen, Hubbard, and Stroh maintain that the libellus mentioned in $C$. 1 contained some portion of poems 2-60. The theory of Wheeler is outlined in $n$. 20 below. For the view that the Catullan corpus in its present form was arranged by the poet cf. T.P. Wiseman, Catullan Questions, Leicester 1969, pp. 1-31; K. Quinn, Catullus: An Interpretation, London 1972, pp. 1-53; Schmidt, loc. cit. pp. 215-242; id. (n. 17), pp. 29-33; Syndikus (n. 2), pp. 52-62.

19 Cf. Wheeler (n. 3), p. 38f.; Santirocco (n. 18), p. 47f.; Krevans (n. 2), pp. 303-306. 
greater asclepiad. The elegiac couplets then, he would have either published as the third part of his libellus or mixed among the polymetrics (to be separated later by another hand) or published separately ${ }^{20}$. In any case, the Garland may have served for Catullus and the other Neoterics as a great source-book of themes, of styles, and of poetic colour; and its miscellany of forms and topics might also have inspired them to write short poems which draw motifs from Hellenistic epigrams and are epigrammatic in character, but are not restricted to the elegiac metre.

\section{Laevius}

Possibly before Meleager edited the Garland, the Roman poet Laevius, whose work belongs to the early decades of the first century B.C., attempted to Romanize Greek lyric metres and used them to compose shorter forms of Latin poetry. There are enough fragments extant to show the character of his work: what is striking is the great variety of metres, 12 or more different kinds ${ }^{21}$, among which are choliambs (fr. 25 Büchner), iambic systems (frs. 1, 4, 6, 15, 18, 23, 27 B.), and two phalaecean lines (fr. 32 B.), these latter being among the metres which Laevius seems to have introduced into Latin poetry ${ }^{22}$. By turning away from Ennius and the older Roman poets to other and Greek forms, he was certainly breaking ground for the Neoteric poets: C. Licinius Calvus, Helvius Cinna, Ticidas, and Furius Bibaculus all used hendecasyllables, iambic metres, and various Aeolic metres in addition to hexameters and elegiac couplets ${ }^{23}$. But Laevius' artistry in aiming at

${ }^{20}$ For the different theories regarding the publication of the Catullan collection cf. n. 18 above. According to Wheeler (n. 3), p. 40, Catullus arranged his short poems in the same way that Meleager did in his Garland, i.e. mixing elegiacs and polymetrics together; just as Meleager's Garland was later broken up and the elegiac pieces were rearranged in the Greek Anthology, so Catullus' elegiac pieces, according to Wheeler, were taken from Catullus' original libelli and put at the end of our edition.

${ }^{21}$ Cf. J. Granarolo, 'L'Epoque néoterique ou la poésie romaine d'avant-garde au dernier siècle de la république (Catulle excepté)', in Aufstieg $u$. Niedergang I 3 , ed. by H. Temporini, Berlin 1973, p. 287; already F. Leo, 'Römische Poesie in der sullanischen Zeit', Hermes 49, 1914, pp. 180-182, esp. n. 2, p. 181.

${ }^{22}$ Evidently Varro in his Saturae also employed these new metres; cf. J.W. Loomis, Studies in Catullan Verse, Leiden 1972, p. 40f.

${ }^{23}$ On the question whether these poets wrote poetic books cf. Krevans (n. 2), p. 309. 
great metrical variety and his evident scholarly interest in metre were not shared by the Roman poets who came after him, as Ross points out; Laevius still stands, in his view, closer to Roman drama than to Alexandrian purposes $^{24}$.

\section{The Hellenistic Epigrams (before Meleager's Collection)}

Catullus and the other Neoterics certainly still read the Greek poetry which initiated Laevius to his metrical experimentation. The hendecasyllable which Laevius seems to have introduced in Latin literature occurs frequently in archaic lyric, for instance in popular songs, Anacreon, and Sappho ${ }^{25}$. Later, in the Hellenistic period, the poets began to adapt these metres, no longer for use in songs but for book lyric ${ }^{26}$. Thus they could widen the repertory of their literary metres: indeed these metres had always been used for short pieces, and such the Callimacheans seem to have preferred ${ }^{27}$. Evidently they did not write strophes but used these kola in stichic and distichic fashion ${ }^{28}$.

24 Ross (n. 11), pp. 156-160; cf. K. Quinn, The Catullan Revolution, reprint ed. Ann Arbor 1971, p. 24. But cf. Krevans (n. 2), p. 307f.: "Even if Catullus followed Laevius in no other regard, rejecting his style and his themes, ... the fact remains that Laevius is the only securely attested collection [of poems by a single author] in mixed metres between Callimachus' Iambi and Catullus".

25 On this metre in general cf. Loomis (n. 22), p. 34ff.; cf. also Wheeler (n. 3), p. 99; Lafaye (n. 10), p. 101; K. Münscher, 'Metrische Beiträge', Hermes 56, 1921, p. 77.

26 On the Hellenistic phenomenon of 'book lyric' cf. W. Kroll, Studien zum Verständnis der römischen Literatur, reprint ed. Darmstadt 1964, p. 202; M. Fantuzzi, 'La contaminazione dei generi letterarî nella letteratura greca ellenistica: rifiuto del sistema o evoluzione di un sistema?', Lingua e stile 15, 1980, p. 441f.; M.L. West, Greek Metre, Oxford 1982, pp. 149-152; G.O. Hutchinson, Hellenistic Poetry, Oxford 1988 , p. 10 n. 14, is more cautious on the assumed contrast between fifth and third century poetry (cf. B. Gentili. Poesia e pubblico nella Grecia antica: Da Omero al V secolo, Roma-Bari 1989², pp. 228-231; Gelzer [n. 16], p. 137).

27 On this poetological principle of Callimachus cf. H. Herter, s.v. 'Kallimachos', R.E. Suppl. XIII, 1973, coll. 195 and 250; most recently E.R. Schwinge, Künstlichkeit von Kunst, München 1986, p. 21, countering W. Wimmel, Kallimachos in Rom, Wiesbaden 1960, p. 76f.; more cautious, again, Hutchinson (n. 26), pp. 78-84.

${ }^{28}$ Cf. West (n. 26), p. 149. On the problem of genre and metre in the Greek epigram cf. B. Gentili, 'Epigramma ed elegia', in L'Epigramme grecque, Entr. Hardt XIV, Vandoeuvres-Genève 1967, pp. 40-43. 
There are a few poems among the epigrams of the Greek Anthology in stichic hendecasyllables, among them one by Phalaecus, who probably gave his name to the metre because he used it more than others (Epigr. 3 Gow-Page; also Theocr. Epigr. 22 Gow; Coll. Alex. p. 194 nos. 28 and 29). In other pieces the hendecasyllable is linked with iambic metres (Theocr. Epigrs. 17 and 20 Gow; Callim. Epigr. 38 Pf.). Theocritus and Phalaecus also wrote epigrams consisting solely of choliambs (Theocr. Epigr. 19 Gow; Phalaec. Epigr. 2 Gow-Page), and other poets used various other iambic metres (Theocr. Epigrs. 17 and 21; Callim. Epigrs. 37-39 Pf.; Phaedimus, Epigrs. 2 and 3 Gow-Page; Leonidas, Epigrs. 2; 23; 68; 79; 90 Gow-Page) ${ }^{29}$. Thus, the fact that the Alexandrians introduced Aeolic and iambic metres from archaic lyric into the genre of the epigram may help to explain why Catullus wrote poems with epigrammatic content in hendecasyllabic and other iambic metres $^{30}$.

But it is only the form and the metre of these short Hellenistic pieces that suggest a relationship with Catullus' collection of polymetrics. There is also a similarity in character. The Hellenistic epigram was a book epigram and had liberated itself from its traditional bondage to epigraphical convention, according to which its purpose was to announce facts like death, victory, the dedication of an object, etc. $^{31}$. From the fourth century B.C. on (the time of Plato, Asclepiades, Poseidippus, etc.) it became "the vehicle of subjective feelings and of portrayals of the most varied experiences"; existing poetical genres were adapted to the epigram, and what before would have been the subject for a poem in lyric metre or an elegy, became a sympotic, erotic, satirical, scoptic, or abusive epigram or the like, where the Alexandrian requirements of brevity, point, and stylistic refinement could be fulfilled ${ }^{32}$. With Callimachus especially the erotic epigrams

${ }^{29}$ Cf. Lafaye (n. 10), p. 101. Callimachus' frs. 399-401 Pf. seem to be epigrams in various lyric metres.

30 Catullus may have read these epigrams in the Garland; but we do not know what poems it contained. Theocritus' epigrams were not among them. Cf. A.S.W. Gow-D.L. Page, Hellenistic Epigrams I, Cambridge 1965, p. XXII.

31 The Hellenistic epigrams, too, became, 'book poetry'; cf. Kroll (n. 26), p. 207f.; Reitzenstein (n. 6), col. 89f.; P.M. Fraser, Ptolemaic Alexandria I, Oxford 1972, p. 560f.; M.L. West, Greek Elegy and Iambus, Berlin-New York 1974, p. 19f.; R. Pretagostini, 'La poesia ellenistica', in F. Montanari (ed.), Da Omero agli Alessandrini, Roma 1988, pp. 322-323; Hutchinson (n. 26), pp. 20-24.

32 Cf. Fraser (n. 31), pp. 560f. and 565 (quotation from p. 560). 
become 'subjective' poetry, although there is little trace of genuine emotion; what strikes the reader is rather "a note of intellectual and (still more) emotional self-criticism, ... free and colloquial expression being combined with artistic and above all metrical refinement" ${ }^{\text {"33 }}$. The lightness and the colloquial tone are characteristics of the epigram from the time of Asclepiades ${ }^{34}$. These are all features which are also attributed to Catullus' poems. Since there is evidence that Catullus drew on the epigram for its formal characteristics and for its motifs, it is also probable that he was influenced by the free and personal character of this poetry.

The epigrams of the third century poets were collected and published in book form, either by the poets themselves ${ }^{35}$ or in anthologies which were compiled by others ${ }^{36}$, so that Catullus might have seen these collections as well as the Garland and been inspired by the arrangement of the poems as well as by their individual content.

However, Catullus in his polymetrical poems and probably the other Neoteric poets as well, as far as we can judge their work, would have had to go beyond the existing traditions and the scope of these short pieces of poetry from the Hellenistic period in order to write a love poem in choliambs, to use hendecasyllables for invective, and to expand 'epigrams' to longer poems.

\section{Callimachus' Iambi}

As Reitzenstein points out, the epigram is, for us, a typical form of Alexandrian poetry only because these poems are extant and well preserved $^{37}$. But the groups of poems which the Alexandrians pub-

33 Ibid. p. 594. On the problem of the term 'subjective' cf. M. Puelma, 'Die Aitien des Kallimachos als Vorbild der römischen Amores-Elegie', Mus. Helv. 39, 1982, p. 227 and n. 22.

${ }^{34}$ Cf. Fraser (n. 31), p. 567. The environment in Alexandria is in some ways comparable to the circle in which Catullus was living, for there was a literary society, there were cliques of poets, and there was a demi-monde; these elements taken all together made up a milieu resembling that of the Neoteric circle as far as we know it. Cf. also Syndikus (n. 2), pp. 11-17.

35 Fraser (n. 31), p. 607, maintains that the poets collected and edited their epigrams themselves.

36 Cf. Santirocco (n. 18), p. 47; Fraser (n. 31), p. 607f. (cf. esp. n. 405).

37 Reitzenstein (n. 6), col. 94. 
lished did not only include epigrams. As the name of the kolon Asclepiadeum shows, Asclepiades must have written poems in lyric metres, and perhaps published them apart from the epigrams. Callimachus wrote four $\mu \varepsilon \dot{\lambda} \lambda \eta$, poems in various lyric metres ${ }^{38}$ of which we have several fragments (226-229 Pf. $)^{39}$; the first piece in Pfeiffer's edition is a hendecasyllabic line ${ }^{40}$. He also wrote thirteen poems (in Pfeiffer's edition these are the Iambi, frs. 191-203) in which he uses choliambs and different other iambic metres (including trimeters). Each poem of the $\mu \varepsilon \dot{\lambda} \eta$ and the Iambi is probably about 30 to 160 lines long ${ }^{41}$ (in most cases we have only bits and pieces). There is some uncertainty as to whether or not all of these seventeen poems were considered as one collection by Callimachus and all called $\operatorname{Iambi}^{42}$; but there is at least some evidence that by the time these poems came to Rome, some 300 years after they were written, all seventeen were indeed combined under the title $\operatorname{Iambi}^{\mathbf{4 3}}$. Especially if one regards all the poems, as the Romans probably did, as belonging to one and the same group, one can say that they follow the principle of variation in topic, genre, and metre $^{44}$ : some of them are on literary subjects (frs. 191; 203; frs. 192 and 194 have the form of a fable); some are erotic $(193 ; 195 ; 199 ; 226)$; one is sympotic (227); there is a propemptikon for a friend who is leaving for Elis (196); there are aetia (200), two being in the form of epigrams (197 ex voto, 201 sepulchral), one leading to a personal attack (199); there are occasional poems, like the genethliakon for the daughter of a friend (202), and the epikedion for Arsinoe (228), the epinikion for an Aeginetan (198, in iambic trimeters [!], which is at the same time an aetion); one looks like a hymn to Apollo and Zeus $(229)^{45}$. The abusive

38 Cf. West (n. 26), pp. 149-152.

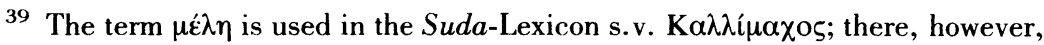
it is not restricted to the four poems which Pfeiffer names Lyrica in his edition. p. 151.

40 The poem was probably written in stichic hendecasyllables; cf. West (n. 26),

41 Cf. C. M. Dawson, 'The Iambi of Callimachus. A Hellenistic Poet's Laboratory', Yale Class. Stud. 11, 1950, p. 143.

42 D.L. Clayman, Catullus' Iambi, Leiden 1980, p. 7, lists the scholars on both sides.

43 Ibid. p. 54.

44 Cf. Dawson (n. 41), pp. 140-149; Puelma (n. 1), p. 231 .

45 Cf. ibid. p. 308f. On Callimachus' epinician poems cf. my Die Auseinandersetzung mit den Chorlyrikern in den Epinikien des Kallimachos, Basel-Kassel 1992, and 
element can be found especially in the erotic poems and those dealing with literary criticism $(191-195 ; 199 ; 203)$.

All these pieces are much longer than Catullus' short poems and are basically different from them in character since they contain myths, fables, and aetia. But nevertheless there are some points of similarity which may indicate that Catullus was influenced by this collection both as a whole and in detail ${ }^{46}$. Let us look at the details first. In the 3rd Iambus (fr. 193) Callimachus complains about his mignon Euthydemus' lack of loyalty; the boy's mother prefers to lease him to a lover who is richer than the poor poet Callimachus (cf. the Diegesis VI 33-40). In Iambus 5 (fr. 195) he advises a teacher in a superficially polite tone to keep his hands off his pupils, especially since, as Puelma suggests, one of them seems to be the boy whom Callimachus would like to have for himself ${ }^{47}$. In these two poems are some elements which have parallels in Catullus. Iambus 3 reminds us of $C$. 24 (in hendecasyllables), in which Iuventius prefers the poor lover Furius, who is bellus, to Catullus $^{48}$. Poems 15 and 21 are hendecasyllables against a rival the pathicus Aurelius; the problem is the same as that represented in Callimachus' 5th Iambus ${ }^{49}$. Thus one can say that it is highly likely that Catullus in some of his Iuventius poems drew on Callimachus' erotic Iambi.

But there are also thematic similarities broader than simply the Iuventius theme. At least in the eyes of the Romans, who thought all seventeen poems were Iambi, Callimachus combined the $\beta \iota \omega \tau \iota x \grave{\eta}$ $\mu(\mu \eta \sigma \iota \varsigma$, an iambic idea characteristic of the Hipponactean tradition (Iambi 1-13) with the 'melic' poetry of the $\mu \varepsilon \dot{\lambda} \eta$. The traditional topics of both iambic and melic poetry were or seemed to be united in poems

my article in M.A. Harder, R.F. Regtuit, G.C. Wakker (eds.), Callimachus ("Hellenistica Groningana I"), Groningen 1993, pp. 79-97.

46 Cf. B. Lavagnini, Da Mimnermo a Callimaco, Torino 1949, p. 105f.; E.A. Schmidt, Philologus 117, 1973, p. 239f. (on the arrangement of the poems); Clayman (n. 42), pp. 72-74; Puelma (n. 33), p. 239 n. 103; B. Arkins, Latomus 46, 1987, p. 848. Krevans (n. 2), p. 314f., sees Callimachus' Aetia as one of Catullus' models for a poetic collection.

47 Puelma (n. 1), p. 262f.

48 Later on this seems to have become a topos; cf. C.W. Macleod, 'Parody and Personalities in Catullus', Class. Quart. 23, 1973, p. $297 f$.

49 With the motif in C. 15, 6-8 Catullus seems to draw on Callimachus' Epigr. 28 where literary criticism is expressed in erotic language; cf. Puelma (n. 1), p. 263. 
that were called Iambi but contained both iambic and lyric metres ${ }^{50}$. Therefore, just as literary and erotic enmities, amatory adventures, poverty, and the poet's own feelings in general were themes of Callimachus' Iambi, so too in Catullus' short poems erotic interests and interpersonal relations are juxtaposed with larger social and literary issues $^{51}$.

But more important than the thematic influence is the influence of the $\pi 0 \iota x \iota \lambda i \alpha$ in metre and genre of the seventeen Callimachean poems ${ }^{52}$. Callimachus defends this practice against his critics in Iambus 13 (fr. 203), where he admits or claims that he mixes Mimnermus and Hipponax, and Ionic and Doric, and different metres, so that ev-

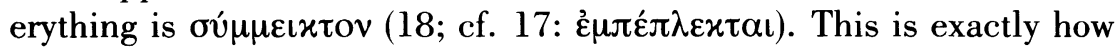
we would describe the character of the Iambi. Clayman (who considers only the thirteen Iambi of Pfeiffer's edition to belong to Callimachus' 'iambic' collection) gives a good description of this phenomenon: "In Callimachus' Iambi the chaos of genre reflects the state of literature after the end of the classical period when no progress seemed possible without dissection, analysis, and ultimately, reconstruction of the old forms" $" 53$. And if we regard the four $\mu \varepsilon \dot{\lambda} \eta \eta$ as a part of the iambic collection - as the Romans probably did - the 'chaos' seems to be even greater. This might have inspired Catullus to publish a collection with such a variety of forms and themes and metres as embraced in Callimachus' seventeen poems. This might also explain why Catullus used phalaecean hendecasyllables in abusive contexts, for Callimachus' poem in this metre (fr. 226) was counted among the Iambi ${ }^{54}$. Thus Catullus does not reserve the term iambi for poems in iambic metres, but seems to use it in a generic sense to indicate invective in any metre $(36,5 ; 40,2 ; 54,6 ;$ fr. 3 Mynors = fr. 2 Bardon). On the other hand,

50 Cf. ibid.pp. 336 and 278-282: Puelma considers Lucilius a forerunner of Catullus in the idea of iambic love poetry; cf. J. Bayet, 'Catulle. La Grèce et Rome', in L'influence grecque sur la poésie latine de Catulle à Ovide, Entr. Hardt II, Vandoeuvres-Genève 1953, p. $24 \mathrm{f}$.

51 Clayman (n. 42), p. 74; cf. Puelma (n. 1), pp. 278-281.

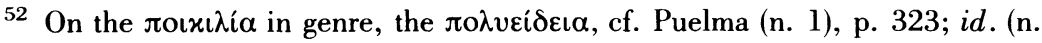

33), p. 293f. and n. 103; Hutchinson (n. 26), p. $55 f$.

53 Clayman (n. 42), p. 82.

54 Cf. A. Ardizzoni, in Miscellanea di studi alessandrini in memoria di Augusto Rostagni (n. 11), p. 261f., who maintains that also the Callimachean poem in hendecasyllables had a iambic, i.e. abusive, character. 
poems 8 and 31 , though written in choliambs, are not abusive - because Callimachus' seventeen poems contain both poems in choliambs and poems that are not abusive (though none that is both choliambic and non-abusive $)^{55}$. And since Callimachus also used features of the traditional epigram in the Iambi, Catullus saw the scope of that genre of short poems enlarged both in form and character ${ }^{56}$.

\section{The 'Crossing of Genres'}

Even if one considers Callimachus' thirteen Iambi and four $\mu \varepsilon \dot{\lambda} \eta \eta$ to be two different groups, there remains in the Iambi this distinctive feature: different traditional genres, for example the sepulchral or dedicatory epigram, the epinician ode, and the genethliakon, are adapted to metres traditionally foreign to them. This is a peculiarity of Alexandrian poetry arising from the two causes outlined above: that under the Alexandrians the earlier Greek lyric had metamorphosed into book poetry, and that they, having a through knowledge of existing traditions, aimed at variation and novelty in all respects. They wrote hymns to gods in elegiac couplets or iambic trimeters ${ }^{57}$, epithalamia in elegiac couplets $^{58}$, epinician odes in iambic trimeters or elegiac couplets ${ }^{59}$; they created new combinations of lyric kola never to be sung, like the catalectic choriambic pentameter used in one of Callimachus' $\mu \varepsilon \dot{\lambda} \eta$ showing hymnal features (fr. 229 Pf.) or the hymn in choriambic hexa-

55 Cf. Puelma (n. 1), p. 336, n. 2; Clayman (n. 42), p. 142. The (lyric) kolon Hipponacteum presumably occurred in the poems of Hipponax; but nothing is known about Hipponactean lyrics (cf. West [n. 26], p. 57 n. 71).

56 The view of F. Della Corte, Due studi catulliani, Genova $1972=$ Opuscula II, Genova 1972, p. 18f., that Catullus' long poems correspond to Callimachus' Aetia, the elegies to the Iambi, and the polymetrics to the $\mu \varepsilon^{\prime} \lambda \eta$, is not fully convincing (it is shared by $\mathrm{H}$. Bardon in the praefatio to his Teubner edition of the Catullan poems, $\mathrm{p}$. IIIf.).

57 For the elegiac couplets ef. Callim. H. 5; SEG 549 and 551 (cf. Fraser [n. 31], p. 671); Crates $S . H .361$ (a parodic hymn to Parsimony). For the iambic trimeters cf. Castorion of Soloi $S . H .310$ (a hymn to Pan; cf. P. Bing, The Well-Read Muse: Present and Past in Callimachus and the Hellenistic Poets, Göttingen 1988, p. 23).

${ }^{58}$ P. Petr. II 49a = P. Lond. Lit. 60 recto; cf. Fraser (n. 31), p. 668, and Pfeiffer on Callim. fr. 392.

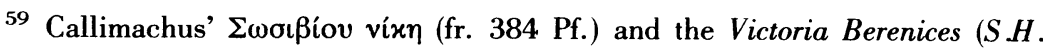
254-268C) in elegiac couplets; Iamb. 8 (fr. 198 Pf.) in iambic trimeters. Cf. Fuhrer, Auseinandersetzung (n. 45), esp. p. 219 . 
meters by the Corcyrean poet Philicus $(S . H .676-680)^{60}$. Wilhelm Kroll has called this phenomenon Kreuzung der Gattungen ${ }^{61}$ : the poet does not feel restricted to write a certain type of a poem in the traditional form but adapts it to a metre which has traditionally been bound to another genre ${ }^{62}$. This freedom opens up various new possibilities for the poet; and that was just what the Callimachean Alexandrian was looking for ${ }^{63}$.

Such must have been the literary situation for Roman poets after they had become familiar with Alexandrian poetry. Catullus and any other Neoteric poet who saw himself as Callimachean could feel free to write epigrams in lyric and iambic metres because there existed such models in Hellenistic poetry and because the metres had been adapted to the Latin language since Laevius' time. In the genre of the epigram the poets could express personal views and feelings of any kind because the book epigram was no longer bound to inscriptional topics. They could also extend epigrammatic poems to considerable length, not only because the Alexandrians had written long epigrams too (cf. e.g. Callim. Epigrs. 1 and 8), but also because Callimachus in his Iambi (typically longer poems) had included some pieces which drew on the traditional type of epigram. Catullus and the other Neoteric poets did not

${ }^{60}$ Cf. Fraser (n. 31), p. 650f.

${ }^{61}$ Cf. also J. Van Sickle, Arethusa 13, 1980, p. 30, who translates "crossing literary breeds"; J.E.G. Zetzel, 'Re-creating the Canon: Augustan Poetry and the Alexandrian Past', Critical Inquiry 10, 1983-84, p. 100, translates "blending of genres".

62 Kroll (n. 26), pp. 202-224; cf. already his article 'Hellenistisch-römische Gedichtbücher', Neue Jahrb. f. Klass. Altert. 37, 1916, esp. p. 94f. Hutchinson (n. 26), p. 15f., however, stresses the "relativelv limited role" of significant crossing. On the mixing of genres, Hutchinson may be right in criticising the paper of L.E. Rossi, 'I generi letterari e le loro leggi scritte e non scritte nelle letterature classiche', Bull. Inst. Class. Stud. London 18, 1971, pp. 69-94 (cf. the remarks of Fantuzzi [n. 26], pp. 433-450, esp. p. 443; A. Cameron, 'Genre and Style in Callimachus', Trans. Am. Philol. Ass. 122, 1992, pp. 305-308). It is true that most of Hellenistic poetry is written in hexameters or elegiac couplets and that the range of the latter had always been extremely wide (cf. A.W. Bulloch, Callimachus: The Fifth Hymn, Cambridge 1985, pp. 34-38); but - without exaggerating the mixing of genres - the transgression of the limits of genres is surely a new approach characteristic to Hellenistic poetry (cf. Hutchinson, loc. cit. p. 55f., on Callimachus' Iambi). Cf. also Bing (n. 57), pp. 22-27.

${ }^{63}$ Horace in his Ars poetica $73-88$ might be polemicising against just this freedom. 
have to break new ground in using the hendecasyllabic and other lyric metres instead of iambs for abusive poetry, since through Callimachus' seventeen Iambi those lyric metres were for them adapted to the en-

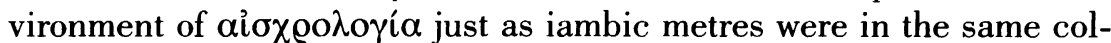
lection adapted to poetry that was not abusive (a propemptikon, an epinikion, a genethliakon). Such a collection composed by a Neoteric could contain virtually any kind of short piece, even a translation of a poem by Sappho or a lyric hymn to Diana, since in Meleager's Garland all kinds of short poems were united ${ }^{64}$.

It is not intended in this paper to suggest that what Catullus or any other Neoteric poet was doing in his poetry was a mere imitation of what was devised by some Greek predecessors. Catullus' achievement, which perhaps also represents the achievement of other Roman poets in the first century B.C., is that he exploited different given possibilities and created, with his group of poems, something that was new both in the use of form and in character ${ }^{65}$.

\section{University of Bern}

64 The passage in C. 50, 4f. (to Calvus) illustrates this mode: scribens versiculos uterque nostrum/ludebat numero modo hoc modo illoc. To play with different forms, however, seems to have been traditional among poets: see Syndikus (n. 2), p. 250f. n. 4. Cf. also L. Landolfi, Quad. Urb. n.s. 24 (53), 1986, p. 86; but only the Hellenistic poets paved the way to the free use of rules visible in Catullus' polymetrics.

65 For differences in character cf. Bayet (n. 50), pp. 20f., 28 and 32; also Fraser (n. 31), p. 563, who claims that the passion of a single and exclusive love is quite missing in the Alexandrian epigrammatists. 